\title{
UPAYA MENINGKATKAN KEBERHASILAN IMPLEMENTASI ERP UNTUK MEMBANGUN KEUNGGULAN BERSAINGPADA UKM DI JAWA TENGAH
}

\author{
Mudiantono \\ Fakultas Ekonomika dan Bisnis, Universitas Diponegoro Semarang \\ Email: mumuk_undip@yahoo.co.id
}

\begin{abstract}
Abstrak
Enterprise Resource Planning (Erp) adalah suatu paket aplikasi perangkat lunak (software) yang terintegrasi untuk digunakan secara luas di organisasi. Penelitian ini bertujuan untuk mengetahui faktor-faktor apa saja yang berpengaruh terhadap keberhasilan implementasi ERP pada Usaha Kecil dan Menengah (UKM) di Jawa Tengah untuk membangun keunggulan bersaing. Untuk membuktikan hipotesis penelitian digunakan data dari 107 responden UKM di Jawa Tengah dengan menggunakan SEM. Hasil analisis data membuktikan bahwa variabel Business Process Reengineering adalah yang paling besar pengaruhnya. Untuk itu disarankan agar para pengusaha kecil dan menengah untuk mempelajari dan memantapkan terlebih dahulu usaha untuk merekayasa ulang bisnisnya sebelum mengimplemantasikan ERP.
\end{abstract}

Kata kunci:Faktor penentu keberhasilan ERP, keunggulan bersaing, UKM.

\begin{abstract}
Enterprise Resource Planning is an integrated software applied in the organization. This study aimed to determine the factors that influence the successful implementation of ERP in Small and Medium Enterprises (SMEs) in Central Java to build competitive advantage. The hypothesis were tested by SEM to 107 respondents. Results of data analysis proved that the variable Business Process Reengineering was the most impact. It recommended that small and medium entrepreneurs to learn and consolidate prior efforts to reengineer its business before applying ERP.
\end{abstract}

Keywords: Successful factors in implementing ERP, strategic competitive advantage, small and medium enterprise.

\section{PENDAHULUAN}

Enterprise Resource Planning (ERP) adalah suatu paket aplikasi perangkat lunak yang terintegrasi untuk digunakan secara luas di organisasi. Sistem (ERP) secara keseluruhan merupakan paket sistem yang terintegrasi penuh dan mendukung otomatisasi di seluruhproses bisnis standar yang ada dalam organisasi. Verville et al. (2005) dan Pricewaterhouse Coopers (1999) menggambarkan sistem ERP sebagai paket sistem inforrnasi yang mengintegrasikan proses informasi dan berbasis informasi dalam dan diluar wilayah fungsional pada suatu organisasi atau suatu set modul yang menghubungkan operasi back office dan front office dalam proses bisnis.

Tidak ada karakteristik khusus bagi perusahaan yang ingin mengimplementasikan ERP. Dahulu hanya perusahaan-perusahaan dengan skala besar saja yang mengimplementasikan sistem ERP mengingat harganya yang sangat mahal dan kebutuhan akan informasi yang cepat dan akurat dengan seluruh bagian dalam perusahaan. Akan tetapi, saat ini banyak perusahaan berskala menengah dan kecilpun telah mulai menerapkan sistem ERP. Beberapa vendor pun telah menyesuaikan produknya untuk perusahaan dengan skala menengah dan kecil dengan biaya yang dapat dijangkau oleh perusahaanperusahaan menengah dan kecil tersebut.

Strategi bisnis yang efektif berpusat pada pemanfaatan teknologi informasi secera efisien dan agresif. Sistem ERP yang berhasil akan merampingkan proses dalam perusahaan dan memperbaiki efektivitas secara keseluruhan dan secara bersamaan menyediakan sarana untuk mendongkrak kinerja kompetitif eksternal, meningkatkan respon atas pelanggan dan bisa dimanfaatkan sebagai pendukung insiatif strategis (Sandoe et al., 2001).

Penelitian Martin (1998) menunjukkan adanya beberapa manfaat dengan membeli paket ERP. Tiga buah manfaat berhubungan dengan masalah bisnis, 
dua manfaat berhubungan dengan teknologi informasi dan sebuah manfaat berhubungan dengan bisnis dan teknologi informasi secara bersama-sama. Ketiga manfaat yang berhubungan dengan bisnis adalah sebagai berikut:

1. Integrasi data yang menyebabkan akses data ke unit bisnis lain, fungsi-fungsi lain, proses-proses dan organisasi meningkat.

2. Menyediakan cara lain untuk melakukan bisnis yaitu lewat rekayasa proses bisnis (business process engineering), menuju ke orientasi proses dan pengurangan biaya proses bisnis.

3. Menyediakan kemampuan global dengan menyediakan globalisasi lewat proses bisnis yang umum dan kelas dunia.

Sistem ERP dapat dianggap sebagai pengembang utama dalam penggunaan teknologi informasi di tahun 1990-an (Davenport, 1998). Implementasi ERP biasanya merupakan suatu proyek besar, kompleks, melibatkan kelompok orang dan sumber daya lain dalam jumlah yang besar, bekerja bersama di bawah ketatnya jadual waktu sesuai dengan yang telah ditetapkan dan menghadapi banyak pengembangan yang tak terduga (customization). Tidak mengherankan, jika banyak dari implementasi ternyata lebih banyak mencapai kegagalan dibanding mencapai keberhasilan sesuai dengan yang diharapkan (Davenport, 1998; Avnet, 1999; Buckhout et al., 1999).

Banyak bukti yang kuat bahwa proyek implementasi sistem ERP tidak dapat diselesaikan tepat pada waktunya dan sesuai dengan anggaran yang ada dan juga dilaporkan secara lengkap bahwa implementasi ERP banyak mengalami kegagalan. Akan tetapi jika sekali sistem ERP berhasil diterapkan, manfaat penting seperti peningkatan layanan peianggan, penjadwalan produksi yang lebih baik dan pengurangan biaya pabrikasi dapat diperoleh. Walaupun tingkat keberhasilan dalam implementasi ERP rendah, akan tetapi beberapa perusahaan yang berhasil mengimplementasikan ERP memperoleh banyak manfaat dari ERP dan telah memanfaatkan sepenuhnya potensi ERP dalam organisasi mereka. Sekitar 90\% implementasi ERP (Martin, 1998) mengalami keterlambatan atau melampaui batas anggaran yang telah ditetapkan dan tingkat keberhasilan dalam implementasi ERP hanya sekitar 33\%.

Winahyu (2005) dalam penelitiannya terhadap 120 perusahaan yang mengimplementasikan dari tiga vendor yaitu PT SAP Indonesia, PT Oracle Indonesia dan PT Mincom Indoservices menghasilkan ada 6 variabel yang menentukan keberhasilan implementasi ERP. Keenam variabel yang terbukti secara signifikan berpengaruh adalah dukungan manajemen puncak, manajemen proyek yang efektif, Business Process Reengineering, pemilihan software dan hardware, pendidikan dan latihan serta dukungan vendor. Sementara itu Nah \& Delgado (2006) menyatakan bahwa terdapat tujuh faktor kunci sukses implementasi ERP yaitu visi dan rencana bisnis, manajemen perubahan, komunikasi, kompensasi dan keahlian tim ERP, dukungan manajemen, manajemen proyek dan pemilihan sistem. Plant and Willcocks (2007) menyebutkan ada empat faktor kunci sukses yaitu dukungan manajemen puncak, sumberdaya terdedikasi, kerjasama antar departemen dan dukungan pemasok.

Survai yang dilakukan oleh Pusat Studi ERP Indonesia tahun 2008 menemukan bahwa tiga masalah utama dalam menerapkan ERP di Indonesia adalah adanya konflik internal, dalam menerapkan ERP adalah dukungan manajemen puncak, kompetensi tim dalam proyek serta pelatihan pelaksana (Pusat Studi ERP Indonesia, 2008). Sebagian besar perusahaan yang mengimplementasikan ERP ini adalah perusahaan dengan skala besar, sementara akhir-akhir ini perusahaan berskala menengah dan kecil sudah mualai memanfaatkan teknologi dalam ERP untuk operasional perusahaan. Sebagian besar dari perusahaan skala menengah dan kecil ini mengimplementasikan ERP meskipun dengan cara yang sangat sederhana melalui penggunaan informasi teknologi yang sederhana pula. Adapun tujuan utama perusahaan mengimplementasikan ERP adalah untuk meningkatkan keunggulan bersaing mereka (Hamilton, 2007). Namun demikian, tingkat kegagalan dalam mengimplementasi ERP ini masih tergolong tinggi $(50-60 \%)$.

Terdapat empat klasifikasi pengguna ERP yaitu klasifikasi A, B, C dan D. Klasifikasi A yaitu perusahaan yang menggunakan seluruh sistem ERP secara efektif pada seluruh perusahaan, klasifikasi B merupakan perusahaan menggunakan secara efektif sebagian sistem ERP untuk seluruh perusahaan. Klasifikasi $\mathrm{C}$ adalah perusahaan yang menggunakan ERP secara formal untuk sebagian perusahaan seperti pencatatan informasi penjualan, penerimaan order pembelian dan aplikasi sistem akuntansi, dan klasifikasi D adalah perusahaan yang mengimplementasikan ERP hanya untuk Sistem Informasi Manajemen (Hamilton, 2004).

Dewasa ini, telah terdapat beberapa modul ERP yang sudah bisa digunakan oleh perusahaan yang masuk kategori Usaha Kecil dan Menengah (Global Solutions, 2012). Bahkan PT Telekomunikasi Indonesia Tbk. (Telkom) telah menghadirkan solusi gratis buat Usaha Kecil dan Menengah melalui Speedy 
ERP Bonastoco yang meliputi Modul Point of Sales (POS), pengelolaan persediaan dan modul akuntansi (Telkom Indonesia, 2010). Modul-modul lain yang bisa digunakan oleh Usaha Kecil dan Menengah ini adalah sebagai berikut: Modul Manajemen Koperasi dan Simpan pinjam, Modul Penjualan, Modul Pembelian, Modul Gudang, Modul Manufaktur, Modul akuntansi, Modul Sumberdaya Manusia, Modul administrasi, Modul Manajemen Dokumen dan Modul Point of Sales (POS)

Kesulitan dan tingkat kegagalan yang tinggi dalam menerapkan sitem ERP telah banvak ditulis dalam literatur (Davenport, 1998). Akibatnya, menurut Larsen \& Myers (1997), bahwa pada suatu implementasi ERP bisa berawal dengan sukses tetapi kemudian akan dapat mengalami kegagalan, sementara itu biaya yang harus ditanggung oleh perusahaan adalah besar, terutama bagi perusahaan berskala kecil dan menengah dengan modal yang terbatas. Oleh karena itu masalah yang diangkat dalam penelitian ini adalah bagaimana meningkatkan keberhasilan implemenatsi ERP untuk membangun keunggulan bersaing Usaha Kecil dan Menengah (UKM) di Jawa Tengah.

Adapun pertanyaan penelitian yang diteliti, antara lain:

1. Apakah Dukungan Manajemen Puncak, Projek Manajemen yang efektif, Business Process Reengineering, pernilihan software dan hardware yang tepat, pendidikan dan pelatihan, serta dukungan vendor berpengaruh terhadap keberhasilan implementasi aplikasi sistem ERP?

2. Apakah keberhasilan implementasi ERP berpengaruh terhadap keunggulan bersaing perusahaan?

\section{LANDASAN TEORI DAN HIPOTESIS}

\section{Faktor-faktor Penentu Keberhasilan Implemen- tasi Sistem ERP}

Faktor-faktor penentu keberhasilan adalah sesuatu yang harus dilakukan oleh organisasi agar tercapainya keberhasilan dalam implementasi sistem ERP. Dalam kaitan dengan sistem informasi proyek, faktor-faktor penentu keberhasilan adalah apa yang harus dilakukan oleh suatu sistem untuk memenuhi apa yang telah dirancang.

Mengacu pada beberapa penelitian terdahulu, maka pada penelitian ini digunakan enam faktor dari faktor-faktor penentu keberhasilan, yaitu Dukungan Manajemen Puncak, Projek Manajemen yang efektif, Business Process Reengineering, Pemilihan software dan hardware, Pendidikan dan Pelatihan serta Dukungan Vendor.

\section{Pengaruh Dukungan Manajemen Puncak Terhadap Keberhasilan Implementasi ERP}

Manajemen puncak harus mempublikasikan secara jelas identifikasi proyek sebagai prioritas utama (Wee, 2000). Manajemen senior juga harus komit dengan keterlibatannya dalam implementasi dan pengalokasian sumberdaya penting dalam implementasi (Holland \& Light, 1999). Hal ini menyangkut penyediaan sumberdaya yang diperlukan untuk implementasi dan menyediakan waktu agar pekerjaan terlaksana dengan baik (Roberts \& Barrar, 1992). Menurut penelitian yang dilakukan oleh Zhang, Lee, Banerjee (2002), dalam Winahyu (2005), dukungan manajemen puncak dalam implementasi ERP mempunyai dua segi utama, yaitu memiliki jiwa kepemimpinan dan menyediakan sumber daya yang diperlukan.

Duchessi, et al. (1998) menyimpulkan bahwa komitmen dari manajemen puncak dan pelatihan yang cukup merupakan faktor-faktor penentu keberhasilan yang penting dalam implementasi ERP. Komitmen dari manajemen puncak harus ditekankan pada seluruh bagian dalam suatu organisasi. Dukungan dari manajemen puncak merupakan faktor kritis pada kelangsungan hidup proyek.

Oleh karena itu hipotesis yang diajukan dalam penelitian ini adalah:

$\mathbf{H}_{1}$ : Semakin besar dukungan manajemen puncak semakin besar keberhasilan dalam implementasi ERP

\section{Pengaruh Manajemen Proyek yang efektif Terhadap Keberhasilan Implementasi ERP}

Mengacu pendapat Lock (1996) dalam Winahyu (2005), yang menyatakan bahwa aktifitas manajemen proyek akan semakin meningkat ketika menerapkan perencanaan, koordinasi dan pengendalian aktivitas yang berbeda dan kompleks dari proyek-proyek komersial dan industri modern.Manajemen proyek mengaplikasikan pengetahuan, teknik dan keterampilan untuk merancang aktivitas proyek sesuai dengankebutuhan proyek. Manajemen proyek terpenuhi melalui penggunaan proses seperti inisialisasi, perencanaan, pelaksanaan, pengendalian dan akhir suatu proyek (Vargas, 2009). Manajemen proyek akan membantu para manager proyek karena akan membantu mereka menstandardisasi tugas rutin mereka dan mengurangi banyaknya tugas yang berpotensi akan terlupakan. Maylor (2001) menjelaskan bahwa suatu dasar teori yangkuattentang manajemen proyek sangat kurang; tetapi akan terbentuk dari waktu ke waktu sehingga sendiri. 
Manajemen proyek dipelajari melalui pengalaman dan telah dikenal sebagai "profesi yang kebetulan".

Menurut Sum, Ang \& Yeo (1997) menjelaskan bahwa suatu manajemen proyek yang efektif adalah dengan menetapkan batasan waktu yang realistis merupakan hal yang penting. Selain itu adanya rencana yang formal yaitu penggunaan metodologi yang tepat dalam implementasi yang sesuat dengan visi perusahaan juga merupakan hal yang penting.

Oleh karena itu hipotesis yang diajukan dalam penelitian ini adalah:

$\mathbf{H}_{2}$ : Semakin efektif manajemen proyek semakin besar keberhasilandalam implementasi ERP

\section{Pengaruh Business Process Reengineering Terhadap Keberhasilan Implementasi ERP}

Business Process Reengineering (BPR) atau rekayasa ulang proses bisnis digambarkan oleh Hammer \& Champy (1993) sebagai pemikiran kembali dan pendesainan ulang proses bisnis untuk meningkatkan kinerja perusahaan dalam hal biaya, kualitas, kecepatan dan layanan. BPR menggabungkan strategi untuk mempromosikan inovasi bisnis dengan strategi untuk melakukan perbaikan besar atas proses bisnis agar perusahaan dapat menjadi jauh lebih kuatserta menjadi pesaing yang lebih berhasil dalam pasar. Perusahaan perlu menetapkan sasaran dan tujuannya yang baru. Visi organisasi dan peranan struktur dari sistem baru harus dikomunikasikan kepada seluruh karyawan. Kebijakan harus ditetapkan oleh manajemen puncak untuk menetapkan sistem baru di perusahaan (Roberts \& Barrar, 1992). Teknologi informasi memainkan peranan penting dalam perekayasaan ulang sebagian besar prosesbisnis. Kecepatan, kemampuan pemrosesan informasi dan konektivitas komputer dapatsecara mendasar meningkatkan efisiensi proses bisnis, seperti juga meningkatkan komunikasidan kerjasama antar orang-orang yang bertanggung jawab atas operasi dan manajemennya.

Faktorpenting lain pada tahap awal proyek adalah Business ProcessReengineering (rekayasa ulang proses bisnis) dan kustomisasi yang minimum. Adalah mutlak bahwa prosesbisnis yang terbentuk disesuaikan dengan sistem yang baru (Bingi et al., 1999). Penyesuaian antara proses bisnis dengan perangkat lunak merupakan faktor penting dalam implementasi (Holland \& Light, 1999 dan Sumner, 1999).

Harus ada keinginan dari organisasi untuk merubah proses bisnis agar sesuai dengan perangkat lunak dengan melakukan kustomisasi yang minimal (Holland \& Light, 1999; Roberts \& Barrar, 1992).
Sebisa mungkin perangkat lunak tidak perlu modifikasi (Sumner, 1999). Modifikasi harus dihindari untuk mengurangi kesalahan dan untuk mempermudah bila akan meng-upgrade ke versi yang lebih baru (Rosario, 2000). Alat-alat untuk proses pemodelanmembantu kustomisasi proses bisnis dengan tanpa mengubah kode pada perangkat lunak (Holland \& Light, 1999).

Adalah penting untuk meninjau ulang dan mendisain ulang proses bisnis (Rosario, 2000). Dalam memilih paketsistem, dukungan vendor dan, banyaknya implementasi yang telah dilakukan sebelumnya, dapat menjadi pertimbangan (Roberts \& Barrar, 1992). Salah satu masalah yang berhubungan dengan penerapan paket sistem adalah ketidak sesuaian antara fasilitas yang tersedia pada software dengan proses bisnis dan kebutuhan informasi organisasi (Janson \& Subramanian, 1996). Baik pada literatur tentang rekayasa (Hammer \& Champy, 1993) maupun pada literatur ERP menyatakan bahwa suatu sistem ERP yang berdiri sendiri tidak bisa meningkatkan kinerja organisasi kecuali jika suatu organisasi mengatur kembali bisnis prosesnya (Bingi et al., 1999). Menurut Willcocks \& Sykes (2000), model bisnis yang baru dan rekayasa ulang yang mendorong pemilihan teknologi adalah suatu faktor yang berperan dalam keberhasilan ERP.

Oleh karena itu hipotesis yang diajukan dalam penelitian ini adalah:

$\mathbf{H}_{3}$ : Semakin baik Business Process engineering yang dilakukan perusahaan semakin besar keberhasilan implementasi ERP.

\section{Pengaruh Pemilihan Software dan Hardware Terhadap Keberhasilan Implementasi ERP}

Paket ERP menyediakan bisnis proses standard dan solusi umum untuk Software bagi para pelanggan. Lebih kurang mereka tidak dapat sepenuhnya memenuhi kebutuhan perusahaan, khususnya bila proses bisnis perusahaan unik/khusus. Dengan demikian, untuk meningkatkan keberhasilan, manajemen harus memilih software yang paling sesuai dengan kebutuhan perusahaan.Para vendor ERP menggunakan platform hardware, sistem operasi dan database yang berbeda dan paket ERP tertentu hanya kompatibel/sesuai dengan beberapa sistem operasi dan database organisasi. Oleh karena itu, pertamatama perusahaan perlu melakukan analisa kebutuhan untuk meyakinkan masalah apa yang perIu untuk dipecahkan dan memilih sistem ERP yang paling cocok dengan kebutuhan mereka. Perangkat keras akan dipilih kemudian menurut kebutuhan sistem ERP yang spesifik. 
Menurut Zhang, Lee \& Banerjee (2002) dalam Winahyu (2005), ada tiga aspek yang harus diperhatikan dalam pemilihan software dan hardware, yaitu:

1. Kesesuaian software/hardware kebutuhan perusahaan

2. kemudahan dalam kustomisasi

3. kemudahan untuk pengalihan ke versi yang lebih tinggi

Oleh karena itu hipotesis yang diajukan dalam penelitian ini adalah:

$\mathbf{H}_{4}$ : Semakin tepat pemilihan software dan hardware yang sesuai dengan kebutuhan perusahaan maka semakin besar keberhasilan dalam implementasi ERP

\section{Pengaruh Pendidikan dan Pelatihan Terhadap Keberhasilan Implementasi ERP}

Pendidikan dan pelatihan mengacu pada proses persiapan bagi karyawan dan manajemen melalui penjelasan-penjelasan tentang logika dan keseluruhan konsep dari system ERP (Martinsons \& Westwood, 1997; Sum, Ang \& Yeo, 1997). Dengan demikian, orang akan dapat memahami dengan lebih baik bagaimana pekerjaan mereka berhubungan dengan area fungsional lain did alam perusahaan itu. User/pemakai adalah orang yang menghasilkan hasil dan bertanggung jawab agar sistem dapat terlaksana sesuai dengan yang diharapkan.

Ada tiga aspek tentang pelatihan, yaitu:

1. Konsep dari pelatihan akan menunjuk kanpa dasetiap orang mengapa sistem ERP diterapkan dan mengapa penggunaan sistem ERP perlu dilakukan.

2. Keunggulan sistem perangkat lunak ERP

3. Pelatihan langsung

Menurut penelitian yang dilakukan oleh Sum, Ang \& Yeo (1997), pelatihan seharusnya tidak terbatas hanya pada pelatihan yang berada dalam spesifik area mereka saja. Melainkan, harus diajarkan logika dan keseluruhan konsep ERP. Pelatihan tentang konsep ERP akan menunjukkan pada karyawan mengapa perubahan (kepada sistem ERP) perlu dilakukan, sedangkan pelatihan fungsional (pelatihan fungsional yang lebih spesifik) akan membantu mengatasi timbulnya rasa takut akan komputer.

Oleh karena itu hipotesis yang diajukan dalam penelitian ini adalah:

$\mathbf{H}_{5}$ : Semakin baik penyelenggaraan pendidikan dan pelatihan semakin besar keberhasilan implementasi ERP.

\section{Pengaruh Dukungan Vendor Terhadap Keber- hasilanI mplementasi ERP}

Kerjasama dengan para vendor/customer sangat penting pada keberhasilan proyek ERP (Stackpole, 1999). Penelitian menunjukkan bahwa kesesuaian yang lebih baik antara perangkat lunak vendor dan pemakai/user organisasi secara positif berhubungan dengan keberhasilan paket implementasi perangkat lunak (Janson \& Subramanian, 1996) dan organisasi itu perlu mencoba untuk terus memaksimalkan kesesuaian mereka dengan vendor mereka (Tong et al., 1994). Hubungan antara vendor perangkat lunak dan penjual secara alami merupakan suatu strategi dengan penyedia ERP untuk meningkatkan daya saing dan efisiensi organisasi. Willcocks \& Sykes (2000) mengidentifikasikan hubungan supplier sebagai suatu kemungkinan penentu yang penting bagi keberhasilan ERP.

Menurut penelitian yang dilakukan oleh Sum et al. (1997), cepatnya tanggapan dalam pelayanan dari vendor perangkat lunak bila timbul masalah merupakan suatu hal yang penting. Tidak adanya dukungan dari vendor perangkat lunak dapat menjadi penghalang dalam proses implementasi ERP. Selain itu vendor eharusnya tidak hanya kompeten dalam teknologi informasi saja, tetapi juga harus banyak mengetahui tentang proses bisnis juga.

Oleh karena itu hipotesis yang diajukan dalam penelitian ini adalah:

$\mathbf{H}_{\mathbf{6}}$ : Semakin besar dukungan yang diberikan pihak vendor semakin besar keberhasilandalan implementasi ERP

\section{Pengaruh Keberhasilan Implementasi ERP Terhadap Keunggulan Bersaing Perusahaan}

Banyak faktor yang dapat dijadikan ukuran bagi keberhasilan penerapan suatu sistem. Menurut DeLone \& Mclean (1992), ketika penggunaan system informasi yang baru diwajibkan, pengukuran pada kualitas sistem, penggunaan sistem dan kualitas informasi pada sistem sebelumnya menjadi kurang bermanfaat. Hal tersebut berasal dari kualitas system itu sendiri dan keluaran informasi yang dihasilkannya. Kepuasan pemakai digunakan untuk mengukur interaksi para pemakai dengan sistem informasi tersebut. Dampak bagi individu dan dampak bagi organisasi merupakan dua ukuran yang digunakan untuk menandai kontribusi sistim informasi bagi para pemakailuser dan kinerja organisasi, yang tampaknya sulit dapat mencapai suatu kesimpulan tanpa mengacu pada beberapa dokumen dari DeLone \& McLean (1992). 
Keunggulan bersaing merupakan posisi yang unik pada suatu organisasi yang berkembang untuk berhadapan langsung dengan para pesaingnya (Hofer \& Schendel, 1978). Keunggulan bersaing dapat berarti sebagai alat-alat penggabungan, akuisisi dan pengambil alihan yang digunakan dalam rangka untuk mencapai suatu ukuran keuntungan. Sistem Informasi sebagai suatu keunggulan bersaing berarti suatu kebutuhan akan perubahandari cara-cara tradisional secara besar-besaran untuk memperoleh keunggulan bersaing atau membentuk kembali industri dan memperluas sistem informasi dalam suatu perusahaan.

Oleh karena itu hipotesis yang diajukan dalam penelitian ini adalah:
$\mathbf{H}_{7}$ : Semakin besar keberhasilan dalam implementasi ERP maka semakin besar keberhasilan dalam mencapai keunggulan bersaing

\section{Kerangka Pemikiran Teoritis}

Model pada penelitian yang merupakan kerangka penelitian teoritis ini menggambarkan pengaruh faktor-faktor penentu keberhasilan (dukungan manajemen puncak, projek manajemen yang efektif, business process reengineering, pemilihan software dan hardware yang tepat, pendidikan dan pelatihan, dukungan vendor), keberhasilan implementasi system ERP serta keunggulan bersaing.Kerangka pemikiran teoritis yang diajukan pada Gambar 1.

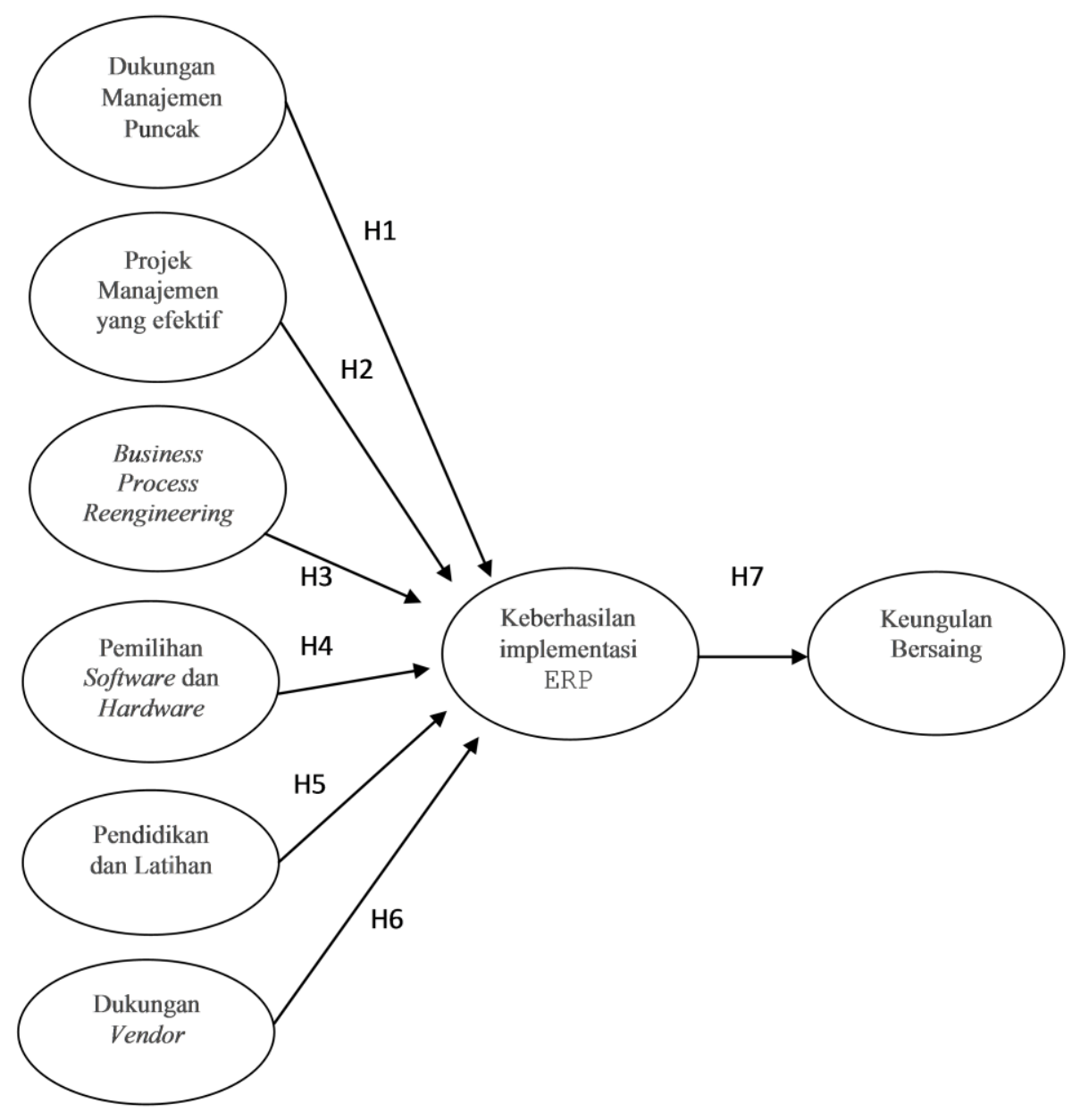

Gambar 1. Kerangka Pemikiran Teoritis

Sumber: Wee (2000), Holland \& Light (1999), Zhang, Lee \& Banerjee (2002), Duchessi, et al. (1998), Sum, et al.

(1997) dalam (Winahyu, 2005) 


\section{METODE PENELITIAN}

Jenis data yang dibutuhkan dalam penelitian ini adalah data primer yang berdasarkan pada indikator dari variabel yang dipakai. Variabel dan indikator tersebut seperti pada Tabel 1.

Penelitian ini difokuskan pada usaha kecil dan menengah. Dengan adanya pembagian perusahaan yang menerapkan ERP ke dalam empat kategori, maka usaha kecil dan menengah termasuk kategori tiga dan kategori empat. Perusahaan dengan kategori tiga dan kategori empat ini akan diambil sebagai sampel dalam penelitian ini. Untuk itu, dalam penelitian ini diambil sampel sebanyak 110 perusahaan dengan cara Quota Sampling. Selanjutnya dilakukan pemilihan sampel secara Covenience Sampling. Hasil analisis menunjukkan bahwa data yang bisa dipakai adalah 107 sampel perusahaan. Oleh karena itu, semua analisis menggunakan data sebanyak 107 reponden. Teknik analisis dalam dalam penelitian ini memakai Structural Equation Model (SEM) dari sofware AMOS yang digunakan untuk menguji $\mathrm{H} 1$ hingga $\mathrm{H} 7$.

\section{HASIL PENELITIAN DAN PEMBAHASAN}

Analisis data merupakan tahapan yang sangat penting dalam suatu penelitian guna mencapai tujuan penelitian. Tujuan penelitian yang tercapai akan bisa memberikan solusi bagi permasalahan yang telah dirumuskan. Analisis data ini akan dilakukan untuk membuktikan apakah keberhasilan implementasi ERP yang dilakukan oleh Usaha Kecil dan Menengah (UKM) di Jawa Tengah betul dipengaruhi oleh dukungan manajemen puncak, manajemen proyek yang efektif, Business Process Reengineering,

Tabel 1. Variabel dan Indikator Penelitian

\begin{tabular}{|c|c|c|c|}
\hline No & Variabel & Indikator & Penelitian Terdahulu \\
\hline 1 & $\begin{array}{l}\text { Dukungan Manajemen } \\
\text { Puncak }\end{array}$ & $\begin{array}{l}\text { - Komitmen pada Proyek } \\
\text { - Penyedia sumberdaya yang diperlukan } \\
\text { - Sikap Kepemimpinan }\end{array}$ & $\begin{array}{l}\text { Wee (2000), Holland \& Light (1999), } \\
\text { Roberts \& Barrar (1992), Zhang, Lee \& } \\
\text { Banerjee (2002) dalam Winahyu (2005), } \\
\text { Duchessi, et al. (1998) }\end{array}$ \\
\hline 2 & $\begin{array}{l}\text { Manajemen Proyek yang } \\
\text { Efektif }\end{array}$ & $\begin{array}{l}\text { - Perencanaan secara formal } \\
\text { - Batasan waktu yang realistis } \\
\text { - Pemantauan status proyek } \\
\text { - Pemimpin proyek yang berpengalaman }\end{array}$ & $\begin{array}{l}\text { Lock (1996) dalam Winahyu (2005), Maylor } \\
\text { (2001), Sum, et al.(1997) }\end{array}$ \\
\hline 3 & $\begin{array}{l}\text { Business Process } \\
\text { Reengineering }\end{array}$ & $\begin{array}{l}\text { Kesediaan perusahaan merekayasa ulang } \\
\text { proses bisnisnya } \\
\text { - Kesiapan perusahaan terhadap proses } \\
\text { bisnisnya } \\
\text { - Kemampuan perusahaan dalam } \\
\text { merekayasa ulang proses bisnisnya } \\
\text { - Komunikasi }\end{array}$ & $\begin{array}{l}\text { Roberts \&Barrar (1992), Bingi et al. (1999), } \\
\text { Holland \& Light (1999), Sumner (1999), } \\
\text { Hammer \& Champy (1993), Willcocks \& } \\
\text { Sykes (2000) }\end{array}$ \\
\hline 4 & $\begin{array}{l}\text { Pemilihan Software dan } \\
\text { Hardware }\end{array}$ & $\begin{array}{l}\text { - Kesesuaian software dan hardware bagi } \\
\text { perusahaan } \\
\text { - Kemudahan dalam Kustomisasi } \\
\text { - Kemudahan pengalihan ke versi yang } \\
\text { lebih tinggi }\end{array}$ & $\begin{array}{l}\text { Zhang, Lee \& Banerjee (2002) dalam } \\
\text { Winahyu (2005) }\end{array}$ \\
\hline 5 & Pendidikan dan Pelatihan & $\begin{array}{l}\text { - Konsep dan Logika ERP } \\
\text { - Keunggulan perangkat lunak ERP } \\
\text { - Pelatihan langsung }\end{array}$ & $\begin{array}{l}\text { Martinsons \& Westwood (1997), Sum et al., } \\
\text { (1997) }\end{array}$ \\
\hline 6 & Dukungan Vendor & $\begin{array}{l}\text { - Kecepatan tanggapan penanganan } \\
\text { perangkat lunak } \\
\text { - Kualitas tenaga Konsultan } \\
\text { - Peran aktif implementasi ERP }\end{array}$ & $\begin{array}{l}\text { Stackpole (1999), Janson \& Subramanian } \\
\text { (1996), Tong, Yap \& Raman (1994), } \\
\text { Willcocks \& Sykes (2000), Sum, Ang \& Yeo } \\
\text { (1997) }\end{array}$ \\
\hline 7 & $\begin{array}{l}\text { Keberhasilan } \\
\text { Implementasi ERP }\end{array}$ & $\begin{array}{l}\text { - Kualitas sistem } \\
\text { - Kualitsa informasi } \\
\text { - } \text { Kepuasan pamakai } \\
\text { - } \text { Dampak terhadap individu dan } \\
\text { perusahaan }\end{array}$ & DeLone \& Mclean (1992) \\
\hline 8 & Keunggulan Bersaing & $\begin{array}{l}\text { - Efisiensi biaya } \\
\text { - Merebut pasar }\end{array}$ & \\
\hline
\end{tabular}

Sumber: Model Penelitian, 2012 
pemilihan software dan hardware, pelatihan dan latihan serta dukungan vendor. Selanjutnya dengan berhasilnya mengimplementasikan ERP akan bisa meningkatkan keunggulan bersaingnya.

\section{Jenis Usaha Responden}

Untuk penelitian ini sampel yang diambil dari kategori kelompok usaha rumah makan, katering dan kuliner yang lain, jasa, toko dan jenis usaha lainnya. Walaupun mereka telah terpilih sebagai responden dan bisa diklasifikasikan ke dalam empat kelompok tersebut, bukan berarti keseluruhan UKM yang telah mengimplementasikan ERP mempunyai proporsi seperti tersebut seperti terlihat pada Tabel 2 .

Tabel 2. Jenis Usaha Responden (dalam persentase)

\begin{tabular}{clr}
\hline No & Jenis Usaha & Jumlah \\
\hline 1 & Rumah Makan, Ketering dan Kuliner yang & 15,89 \\
& lain & \\
2 & Jasa & 37,38 \\
3 & Toko & 39,25 \\
4 & Lainnya & 7,48 \\
\hline & Jumlah & 100,00 \\
\hline
\end{tabular}

Sumber: Data primer yang diolah, 2012

\section{Jenis Modul yang Digunakan Responden}

Untuk ERP yang digunakan oleh perusahaan mempunyai jenis modul yang sangat bervariasi. Namun untuk UKM masih terbatas jenis modul yang bisa digunakan. Seperti yang sudah dijelaskan di awal bahwa terdapat 10 modul yang bisa digunakan oleh perusahaan yang termasuk dalam UKM. Dari kesepuluh modul yang tersedia, ternyata modul administrasi yang paling banyak digunakan oleh responden yaitu sebesar $17,79 \%$. Selanjutnya modul sumberdaya manusia dan penjualan. Perbedaan prosentase penggunaan jenis modul tidak terlalu besar, hanya yang paling sedikit digunakan adalah untuk keperluan koperasi dan manufaktur.

Tabel 3. Jenis Modul yang Digunakan Responden (dalam persentase)

\begin{tabular}{clr}
\hline No & Jenis Modul & Jumlah \\
\hline 1 & Manajemen Koperasi dan Simpan Pinjam & 1,23 \\
2 & Penjualan & 15,54 \\
3 & Pembelian & 9,82 \\
4 & Gudang & 8,18 \\
5 & Manufaktur & 1,64 \\
6 & Akuntansi & 12,27 \\
7 & Sumberdaya Manusia & 15,95 \\
8 & Administrasi & 17,79 \\
9 & Manajemen Dokumen & 5,93 \\
10 & Point of Sales & 11,65 \\
\hline & Jumlah & 100,00 \\
\hline
\end{tabular}

Sumber: Data primer yang diolah, 2012

\section{Pengujian Model Penelitian}

Selanjutnya adalah melakukan analisis Structural Equation Model (SEM) secara full model yang

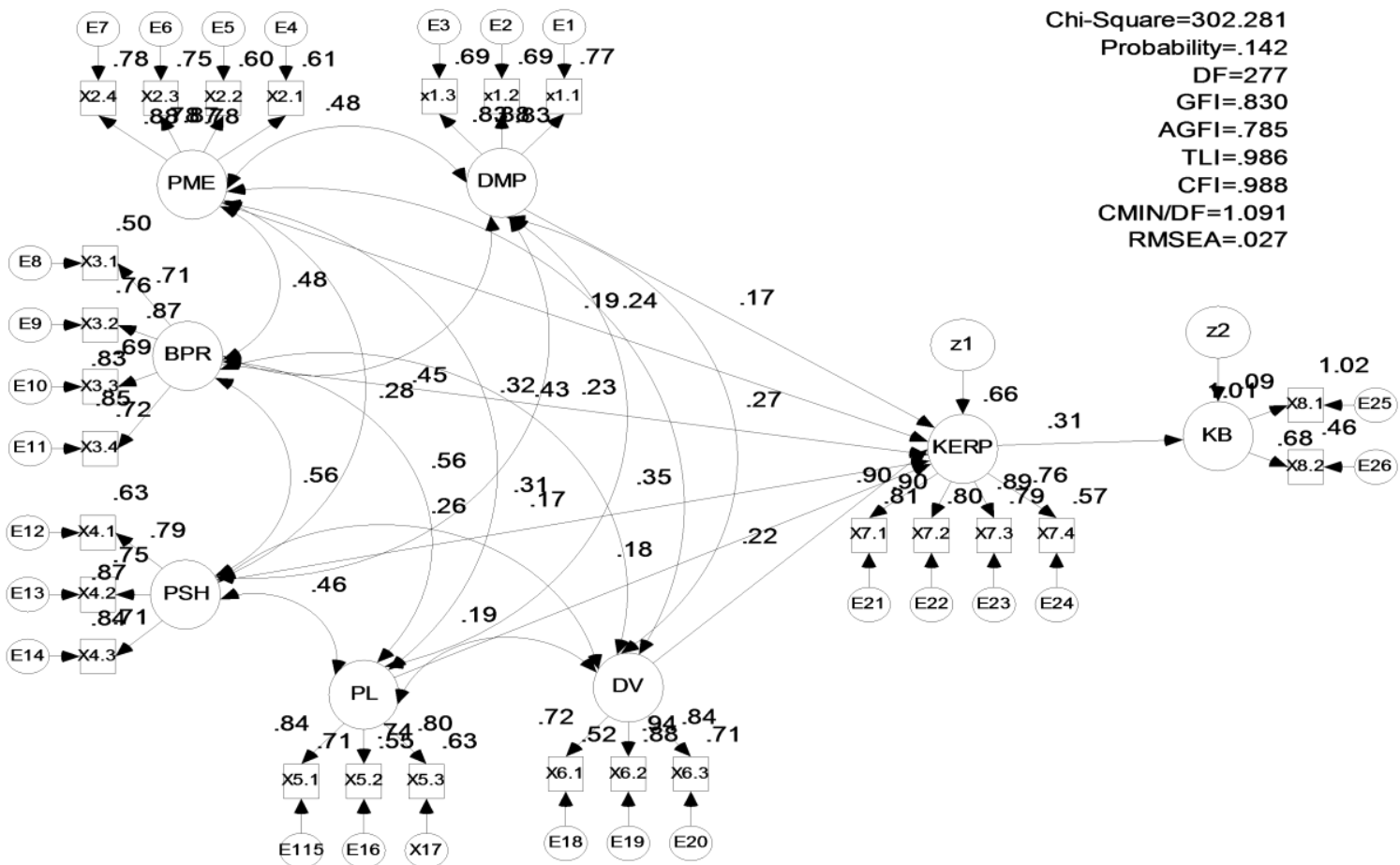

Gambar 2. Hasil Uji Structural Equation Model

Sumber: Data primer yang diolah, 2012 
ditujukan untuk menguji model dan hipotesis yang dikembangkan dalam penelitian ini. Penggunaan SEM dilakukan karena SEM mampu menjelaskan model yang rumit seperti model yang digunakan dalam penelitian ini. Pengujian model dalam SEM dilakukan dengan dua pengujian yaitu uji kesesuaian model dan uji signikansi kausalitas melalui uji koefisien regresi. Hasil pengolahan data untuk analisis SEM terlihat pada Gambar 2, Tabel 4 dan Tabel 5.

Berdasarkan hasil pengamatan pada Gambar 2 di atas tentang grafik analisis model dapat dilihat bahwa model memenuhi kriteria fit. Hal ini ditandai oleh nilai dari hasil perhitungan yang memenuhi kriteria layak full model.

Hasil seperti terlihat pada Tabel 4 di atas menunjukkan bahwa model keseluruhan memenuhi kriteria model fit. Di samping kriteria diatas observed (indikator) dari konstruk adalah valid karena mempunyai nilai diatas 0,5 sehingga tidak satupun observed (indikator) yang didrop (dibuang).

Berdasarkan Gambar 2 dan Tabel 5 bahwa model yang dipakai dalam penelitian ini dapat diterima.

\section{Tabel 4. Hasil Uji Full Model}

\begin{tabular}{llll}
\hline \multicolumn{1}{c}{ Criteria } & \multicolumn{1}{c}{ Cut of Value } & Hasil & \multicolumn{1}{c}{ Evaluasi } \\
Chi-Square & $X^{2}$ dengan df:277 & 302,281 & BAIK \\
Probability & p 5\%=316.819 & 0,142 & BAIK \\
GFI & $\geq 0,05$ & 0,830 & MARGINAL \\
AGFI & $\geq 0,90$ & 0,785 & MARGINAL \\
TLI & $\geq 0,90$ & 0,986 & BAIK \\
CFI & $\geq 0,95$ & 0,988 & BAIK \\
CMIN/DF & $\geq 0,95$ & 1,091 & BAIK \\
RMSEA & $\leq 2,00$ & 0,027 & BAIK \\
& $\leq 0,08$ & & \\
\hline
\end{tabular}

Sumber: Data primer yang diolah, 2012

Tabel 5. Hasil Regression Weights Analisis Structural Equation Modeling

\begin{tabular}{|c|c|c|c|c|c|c|}
\hline & & Estimate & S.E. & C.R. & $\mathbf{P}$ & Label \\
\hline KERP & $<---$ DMP & 0.136 & 0.064 & 2.133 & 0.033 & \\
\hline KERP & <--- PME & 0.138 & 0.059 & 2.348 & 0.019 & \\
\hline KERP & <--- BPR & 0.2 & 0.09 & 2.222 & 0.026 & \\
\hline KERP & $<--$ PSH & 0.133 & 0.067 & 1.997 & 0.046 & \\
\hline KERP & $<---$ PL & 0.138 & 0.067 & 2.075 & 0.038 & \\
\hline KERP & $<--$ DV & 0.182 & 0.06 & 3.013 & 0.003 & \\
\hline $\mathrm{KB}$ & <--- KERP & 0.387 & 0.114 & 3.396 & *** & \\
\hline
\end{tabular}

Sumber: Data primer yang diolah, 2012.

\section{Pengujian Hipotesis Penelitian}

Tahap berikutnya adalah untuk menguji hipotesis penelitian yang diajukan sebelumnya. Pengujian hipotesis ini didasarkan atas pengolahan data penelitian dengan menggunakan analisis SEM.
Pengujian hipotesis ini adalah dengan menganalisis nilai Critical Ratio (CR) dan nilai Probability (P) hasil olah data, dibandingkan dengan batasan statistik yang disyaratkan, yaitu di atas 1,96 untuk nilai CR dan di bawah 0,05 untuk nilai P. Apabila hasil olah data menunjukkan nilai yang memenuhi syarat tersebut, maka hipotesis penelitian yang diajukan diterima. Secara keseluruhan seperti tampak pada Tabel 5 dapat disimpulkan bahwa semua hipotesis yang dibentuk adalah diterima.

Hipotesis 1 membuktikan bahwa ada pengaruh yang searah dukungan manajemen puncak dengan keberhasilan implementasi ERP. Hal ini mendukung penelitian Wee (2000), Holland \& Light (1999), Roberts \& Barrar (1992), Zhang, Lee \& Banerjee (2002) dalam Winahyu (2005) dan Duchessi, et al. (1998) yang menyimpulkan bahwa komitmen dari manajemen puncak, untuk UKM bisa pemilik, merupakan penentu keberhasilan implementasi ERP. Komitmen manajemen puncak (pemilik) merupakan faktor kritis pada kelangsungan proyek, karena pada UKM sering keputusan pemilik menjadi mutlak.

Hipotesis 2 membuktikan bahwa ada pengaruh yang positif manajemen yang efektif terhadap keberhasilan implementasi ERP. Hasil ini mendukung penelitian yang dilakukan oleh Lock (1996), Maylor (2001) dan Sumet al.(1997) yang mengatakan bahwa manajemen proyek yang efektif melalui penetapan waktu realistis dengan adanya rencana formal yang menggunakan metodologi yang tepat dalam implementasi yang sesuai dengan visi perusahaan merupakan faktor penting. Kelemahan utama UKM adalah dalam hal perencanaan, oleh karena itu untuk mengimplementasikan ERP ini UKM yang mempunyai perencanaan yang bagus akan lebih mudah.

Hipotesis 3 yang membuktikan bahwa ada pengaruh positif Business Process Reengineering terhadap keberhasilan implementasi ERP. Hasil ini mendukung penelitian yang dilakukan oleh Roberts \& Barrar (1992), Bingi, et al. (1999), Holland \& Light (1999), Sumner (1999) dan Willcocks \& Sykes (2000) yang menyatakan bahwa penyesuaian antara proses bisnis yang dilakukan dengan perangkat lunak yang dipakai adalah faktor penting untuk keberhasilan implementasi ERP. Kesiapan UKM melakukan rekayasa ulang bisnisnya akan sangat membantu terutama kesiapan pemilik untuk menetapkan visi perusahaannya.

Hipotesis 4 membuktikan bahwa pemilihan software dan hardware menentukan keberhasilan implementasi ERP. Hal ini mendukung penelitian yang dilakukan oleh Zhang, Lee \& Banerjee (2002) dalam Winahyu (2005) yang menyatakan bahwa pemilihan software dan hardware harus disesuaikan 
dengan kebutuhan perusahaan, mengingat investasinya sangat mahal. Selain itu sistem ERP yang dipilih harus mudah dalam kustomisasi yang akan mempermudah dalam pengalihan ke versi yang lebih tinggi.

Hipotesis 5 membuktikan bahwa ada pengaruh Pendidikan dan Pelatihan terhadap keberhasilan implementasi ERP. Temuan ini mendukung penelitian yang telah dilakukan oleh Martinsons \& Westwood (1997) dan Sumet al. (1997) yang mengacu bahwa proses persiapan bagi karyawan dan manajemen melalui proses penjelasan tentang logika dan keseluruhan konsep sistem ERP menjadi faktor yang penting. Dengan demikian orang bisa lebih memahami akan pekerjaan mereka yang berhubungan dengan area fungsional di dalam perusahaan sehingga akan bertanggung jawab agar sistem bisa berjalan dengan baik. Kesediaan untuk belajar bagi semua karyawan terutama bagi pemilik harus didorong.

Hipotesis 6 membuktikan bahwa dukungan vendor berpengaruh positif terhadap keberhasilan implementasi ERP. Hasil ini mendukung penelitian yang dilakukan oleh Stackpole (1999), Janson \& Subramaniam (1996), Tong, et al. (1994), Willcocks $\&$ Sykes (2000) dan Sum et al. (1997) yang menyatakan bahwa cepatnya tanggapan dalam pelayanan dari vendor bila timbul masalah merupakan faktor penting. Selain itu vendor seharusnya tidak hanya kompeten dalam teknologi informasi saja, akan tetapi harus banyak mengetahui tentang proses bisnis juga.

Pengujian hipotesis 7 dilakukan untuk membuktikan bahwa dengan keberhasilan implementasi ERP akan meningkatkan keunggulan bersaing dari UKM. Hasil ini mendukung penelitian yang dilakukan oleh DeLone \& McLean (1992) yang menyatakan bahwa dengan keberhasilan implementasi ERP akan mampu meningkatkan UKM dalam bersaing serta bisa berkonsentrasi untuk merebut pasar. Perusahaan akan dengan cepat bisa bergerak dan menyesuaikan dengan kondisi pasar.

\section{KESIMPULAN DAN SARAN}

Dengan jumlah responden sebanyak 107 UKM di Jawa Tengah dan diolah dengan SEM, diperoleh pembuktian bahwa semua hipotesis diterima. Hasil ini secara keseluruhan mendukung penelitian yang dilakukan oleh Winahyu (2005) dan Nah \& Delgado (2006), dengan perbedaannya adalah kedua penelitian tersebut dilakukan pada perusahaan besar sementara penelitian ini menggunakan perusahaan skala kecil dan menengah. Dari enam variabel yang berpengaruh terhadap keberhasilan implementasi ERP, variabel Business Process Reengineering mempunyai koefisien regresi (regression weight) yang paling tinggi
$(0,20)$ atau dengan kata lain variabel ini paling berpengaruh terhadap keberhasilan implementasi ERP, seperti terlihat pada Gambar 2. Urutan selanjutnya setelah Business Process Engineering adalah Dukungan Vendor (0,182), Manajemen Proyek yang Efektif $(0,138)$, Pendidikan dan Pelatihan $(0,138)$, Dukungan Manajemen Puncak $(0,136)$ dan Pemilihan software dan hardware $(0,133)$. Hasil koefisien regresi ini memberikan gambaran urutan pengaruh dari masing-masing variabel, untuk kemudian dapat disusun skenario untuk meningkatkan keberhasilan dalam implementasi ERP. Selanjutnya dengan kerberhasilan dalam implementasi ERP maka keunggulan bersaing diharapkan dapat tercapai.

Skenario 1: Semakin baik dalam Business Process Reengineering maka semakin besar keberhasilan dalam implementasi ERP. Variabel ini dibentuk oleh empat dimensi yaitu kesediaan perusahaan merekayasa, kesiapan perusahaan dalam proses bisnisnya, kemampuan perusahaan dalam merekayasa ulang proses bisnisnya dan komunikasi. Di antara empat dimensi ini, kemampuan perusahaan dalam merekayasa ulang proses bisnisnya mempunyai regression weight yang paling tinggi yaitu 0,949. Dimensi ini memberikan petunjuk bahwa UKM akan berhasil mengimplementasi ERP apabila mereka mampu mempertegas visi dan misi perusahaannya untuk kemudian menata kembali langkah-langkah untuk mencapai visi dan misinya. Dengan mempertegas visi dan misi serta merekayasa ulang proses bisnis yang dilakukan dengan menggunakan teknologi informasi yang tersedia maka diharapkan akan bisa meningkatkan keunggulan bersaingnya, meskipun modul yang digunakan masih sederhana. Namun demikian, dengan dipakainya modul ERP maka akan memberikan sesuatu yang beda dan diharapakan akan menjadi keunggulan perusahaan dalam bersaing.

Skenario 2: Langkah selanjutnya adalah dengan meningkatkan dukungan vendor untuk berhasil dalam mengimplementasi ERP. Dukungan vendor ini dibentuk oleh tiga dimensi yaitu kecepatan tanggapan penanganan software, kualitas tenaga konsultan dan peran aktif implementasi ERP. Dari ketiga dimensi ini yang paling tinggi regression weightnya adalah kecepatan tanggapan penanganan software $(0,925)$. Ketepatan pemilihan vendor merupakan hal yang positif untuk bisa meningkatkan keberhasilan implementasi ERP. Kontrak yang jelas seringkali diabaikan baik oleh perusahaan maupun vendor. Vendor sering lalai dan mengabaikan keluhan dari perusahaan kecil dan menengah. Jika terjadi masalah dalam pemakaian modul dan vendor tidak segera menanggapi, maka yang terjadi adalah kemacetan dalam bisnis. 
Skenario 3: Manajemen proyek yang efektif merupakan variabel selanjutnya yang harus diperhatikan untuk ditingkatkan agar supaya implementasi ERP juga bisa meningkat. Variabel ini dibentuk oleh empat dimensi yaitu perencanaan secara formal, batasan waktu yang realistis, pemantauan status proyek dan pemimpin yang berpengalaman. Dari keempat dimensi ini, pemimpin yang berpengalaman mempunyai regression weight yang paling tinggi yaitu 0, 941. Implementasi ERP berawal dari pekerjaan proyek. Apabila sudah terpasang dan dilakukan uji coba yang hasilnya siap diimplementasikan maka bisa dikatakan sebagai pekerjaan rutin yang sudah menyatu bagi operasi perusahaan. Oleh karena itu, pemilihan pemimpin yang berpengalaman akan sangat berpengaruh bagi berhasilnya implementasi ERP. Pengalaman di sini tentunya pengalaman dalam implementasi ERP sebelumnya baik dengan modul yang lengkap maupun yang sederhana untuk perusahaan kecil dan menengah.

Skenario 4: Meningkatkan variabel pendidikan dan pelatihan dengan harapan keberhasilan implementasi ERP dapat meningkat juga. Variabel ini dibentuk oleh tiga dimensi yaitu konsep dan logika ERP, keunggulan perangkat lunak (software) ERP dan pelatihan langsung. Dari ketiga dimensi ini, yang paling tinggi regression weightnya adalah konsep dan logika ERP $(0,925)$. Hal ini bisa dimengerti, bagaimana suatu modul ERP akan bisa dilaksanakan apabila konsep dan logika ERP tidak bisa dimengerti oleh pelaksananya.

Skenario 5: Variabel Dukungan Manajemen Puncak menjadi skenario lima karena hanya menghasilkan regression weight sebesar 0,136 . Variabel ini dibentuk oleh tiga dimensi yaitu komitmen pada proyek, penyedia sumberdaya yang diperlukan dan sikap kepemimpinan. Dari tiga dimensi ini, sikap kepemimpinan merupakan dimensi yang paling tinggi pengaruhnya $(0,92)$. Penetapan visi dan misi perusahaan serta upaya untuk mencapainya adalah berasal dari sikap kepemimpinan. Sikap kepemimpinan harus tegas untuk mau mengimplementasikan ERP.

Skenario 6: Skenario terakhir adalah meningkatkan keberhasilan implementasi ERP adalah pemilihan software dan hardware. Variabel pemilihan software dan hardware ini dibentuk oleh tiga dimensi yaitu kesesuaian software dan hardware bagi perusahaan, kemudahan dalam kustomisasi dan kemudahan pengalihan ke versi yang lebih tinggi. Dari tiga dimensi ini, dimensi kemudahan dalam kustomisasi merupakan dimensi yang paling tinggi pengaruhnya $(0,956)$. Oleh karena itu, perusahaan UKM perlu mencari modul yang paling mudah digunakan untuk para penggunanya. Apabila sudah bisa berkembang penggunaannya dan manfaatnya besar bagi operasional perusahaan maka bisa dikembangkan lebih lanjut.

\section{DAFTAR REFERENSI}

Avnet. 1999. ERP not Living Up to Promise, Global Supply Chain, 2(1): 7.

Bingi, P., Sharma, M. K., \& Godla, L. K. 1999. Critical Issues Affecting an ERP Implementation, Information Systems Management, 16(3), 7-14.

Buckhout, S. F., E. \& I, N. I. 1999. Making ERP Succeed: Turning Fear Into Promise, Strategy \&Business, 15(2): 60-72.

Davenport, T. 1998. Putting the Enterprise into the Enterprise System, Harvard Business Review, July-August, 121-131.

DeLone, W. H. \& McLean, E. R. 1992. Information Systems Success: The Quest for the Dependent Variable, Information Systems Research, 3(1): 60-95.

Duchessi, P., Schaninger C. \& Hobbs, D. 1989. Implementing a Manufacturing Planning and Control Information System, California Management Review, 31(3): 75-90.

Global Solutions. 2012. Kelebihan ERP Berbasis Web dibandingkan ERP Berbasis Desktop. Retrieved April 1, 2012 from http://www.mentaya.co.id/mty16/.

Hamilton, S. 2004.Classification of ERP Success. Retrieved April 1, 2012 from www.technologyevaluation.com.

------. 2007.Justification of ERP Investment. New York: McGraw-Hill.

Hammer, M. \& Champy, J. 1993. Reengineering the Corporation: A Manifesto for Business Revolution, New York: Harper Business.

Hofer, C. S. \& Schendel, D. 1978. Strategy Formulation: Analytical Concepts. St. Paul: West Publishing Co.

Holland, C. P. \& Light, B. 1999. A Critical Success Factors Model for ERP Implementation, Journal IEEE Software, 16(3): 30-36.

Janson, M. A. \& Subramanian, A.. 1996. Packaged Software: Selection and Implementation Policies, INFOR, 34(2): 133-151

Larsen, M. A. \& Myers, M. D. 1997. BPR Success or Failure? A Business Process Reengineering Model in the Financial Services Industry, ICIS '97 Proceedings of the International Conference on Information System, Atlanta, pp. 367-82.

Martin, M.H. 1998. An ERP Strategy, Fortune, pp.95-97. 
Martinsons, M. G. \& Westwood, R. I. 1997. Management Information Systems in the Chinese Business Culture an Explanatory Theory, Information \&Management, 32(5): 215-228.

Maylor, H. 2001. Beyond the Gantt ChartProject Management Moving On, European Management Journal, 19(1).

Nah, F. F. \& Delgado, S. 2006. Critical Success Factors for Enterprise Resource Planning Implementation and Upgrade, The Journal of Computer Information Systems, 46(5): 99

Plant, R. \& Willcocks, L. Spring 2007. Critical Success Factors in International ERP Implementation: A Case Research Approach, The Journal of Computer Information Systems, p. 60-70.

Pricewaterhouse Coopers. 1999. Technology Forecast. 1999, $10^{\text {th }}$ Anniversary ed, Pricewaterhouse Coopers Technology Center, Menlo Park, CA.

Pusat Studi ERP Indonesia. 2008. Retrieved April 1, 2012 from http://www.erpweaver.com.

Roberts, H. J. \& Barrar, P. R. N. 1992. MRPII Implementation: Key Factors for Success, Computer Integrated Manufacturing Systems, 5(1): 31-8.

Rosario, J. G. 2000. On the Leading Edge: Critical Success Factors in ERP Implementation Projects, Business World, 17: 15-29

Sandoe, K., Corbitt, G. \& Boykin, R. 2001.Enterprise Intergration, New York: Wiley

Stackpole, B. 1999. Vendor/Customer Partnership are Vital, ERP Hub. Retrieved April 1, 2012 from wysiwyg://136/http://www.erphub.com/ performance_9906ent.html, 1/5/2000.

Sum, C. C., Ang, J. S. K.\&Yeo, L. N. 1997.Contextual Elementsof Critical Success Factors in MRP Implementation, Production and Inventory Management Journal, 38(3):77-83.
Sumner, M. 1999. Critical Success Factors in Enterprise Wide Information Management Systems. Proceedings of the Americas Conference on Information Systems, Milwaukee WI, pp. 232234.

Telkom Indonesia. 2010. TELKOM Launch Bonastoco Integrated Accounting Application Solution for UKM. Retrieved April 1, 2012 from http://www.telkom.co.id/media-corner/pressrelease/telkom-launch-bonastoco-integratedaccounting-application-solution-for-ukm.html.

Tong, J. Y. L., Yap, C. S. \& Raman, K. S. 1994. Engagement of External Expertise in Information Systems Implementation, Journal of Management Information Systems, 11(2): 209231.

Vargas, R. 2009. A New Approach to PMBOK 2000. Retrieved April 1, 2012 from http://www. ricardo-vargas.com/articles/pmbokguide2000/.

Verville, J., Hallingten, A. \& Bernadas, C. 2005. So You're Thingking of Buying an ERP? Ten Critical Factors for Successful Acquisition, Journal of Enterprise Information Management, 18(6): 665-677.

Wee, S. 2000. Juggling Toward ERP Success: Keep Key Success Factors High, ERP News, February 2000. Retrieved April 1, 2012 from http://www.erpnews.com/erpnews/erp904/02get.h tml.

Winahyu, T. R. 2005. Analisis Faktor-Faktor Penentu Keberhasilan Dalam Implementasi Paket Sistem Enterprise Resource Planning (ERP) Untuk mencapai Keunggulan Bersaing Perusahaan, M.M., Universitas Diponegoro Semarang.

Willcocks, L. P. \& Sykes, R. 2000. The Role of the $\mathrm{CIO}$ and IT Function in ERP, Communications of the ACM, 43(4): 32-38. 